\title{
THE EFFECTIVENESS OF COLLABORATIVE STRATEGIC READING ON STUDENTS' READING COMPREHENSION
}

\author{
Yusi Anita \\ (uci.aniet@gmail.com) \\ Universitas Kanjuruhan Malang
}

\begin{abstract}
The objective of this research was to find whether collaborative strategic reading was effective to improve students' reading comprehension on SMPN 1 Gondanglegi Malang. The participants are students from $8 \mathrm{D}$ and $8 \mathrm{C}$ Class. The first group was $8 \mathrm{D}$ as the experimental group, and the control group was $8 \mathrm{C}$. The data mainly came from statistical results, including the questionnaire responses. The scores of both groups were analyzed by using independent sample t-test. The result of independent sample t-test showed that the probability (p) was less than level of significant which is 0.05 , it was .000 . It means there is a significant difference between students who are taught by using Collaborative Strategic Reading than they who are not. The mean score obtained by experimental group was higher than the mean score obtained by the control group (74.58 > 62.66). It shows that there was a positive effect after applying Collaborative Strategic Reading in the experimental group. Thus, it can be concluded that Collaborative Strategic Reading is effective to improve students' reading comprehension.
\end{abstract}

Keywords: Collaborative Strategic Reading, Reading Comprehension, Effectiveness

\section{INTRODUCTION}

In ELT, reading becomes one of English skills that the value cannot be ignored in all education fields. By reading, most information will be gotten by the students. It means they read and they will know what they have never known before, whether in the past, present or even in the future. As Grabe and Staller in Nikmah (2013) said that "reading is the ability to draw meaning from the printed page and interpret this information appropriately". Furthermore, reading develops students' mind. Students will learn new vocabularies, and unconsciously they apprehend the information on how to structure sentences and how to use the words in the other context successfully in writing and speaking. In addition, according to Heilman, Blair in Putri (1981), "Reading comprehension is a process of making sense of written ideas through meaningful interpretation and interaction with language". To get those benefits in reading, the students should comprehend what they have read. Therefore, reading comprehension is needed by the students.

In fact, not all students at school like reading. Some students show enthusiasm when they meet reading texts. However, some students show rejection. There are some problems that students face in understanding a text. One of them is they have same difficulties in understanding the word. When they have lack of vocabularies, It becomes based problem to the most students because when they don't know the meaning, they will get the difficulty in comprehending the text. Besides, students feel bored during process of teaching and learning in reading class. Mostly, they will ignore to comprehend the meaning because of the strategy that the teacher use is monotonous, so it will decrease their enthusiasm. To coverage the students' problems in comprehending 
the text, teachers are demanded to be able to choose the appropriate strategy to help the students.

There are some strategies in reading; one of them is collaborative strategic reading (CSR). Klingner and Vaughn have founded Collaborative Strategic Reading in 1987. "This strategy combines modification of Reciprocal Teaching and cooperative learning strategy" (Abidin \& Riswanto, 2012). CSR has four stages: preview, click and clunk, get the gist and wrap up in which each stage will lead the students read purposefully. This strategy is better to be applied simultaneously with cooperative learning, in which students are able to work in group.

There are two phases in implementing Collaborative Strategic Reading (CSR) in the classroom. In phase one, teacher demonstrates how to implement CSR based on his instruction (Teacher Based Instruction). In this phase, according to Klingner students learn four strategies: preview, click and clunk, get the gist, and wrap-up. Preview is a pre-reading activity. In this section teachers should explain what students have to do during the reading and also ask them to predict what they will learn about the text. It will activate students' prior knowledge and motivate students' interest in reading. After previewing, Click and Clunk is the first strategy that is implemented during reading process aiming to help students clarify meaning.

Teacher should help students how to comprehend the text by asking them to find the difficult words in the text (Click) and asking them also to make sense on the words that they have found in the text (Clunk). To fix the clunk, students use fix-up strategies to figure it out the difficult words or ideas. Teacher can ask the students to reread the sentence and look around the difficult words to help them understand it and make sense on it, or they reread the text to look for clues. Afterwards, students learn get the gist by identifying the important idea in the text. Teacher asks them to identify the important point such as person, place or thing in the text by give them questions and try to make them to answer it in their own words. Then, wrap-up will close the whole process of reading activity by formulating questions using: who, what, when, where, why, and how about what they have learned and by reviewing key ideas. The goals of this section are to improve students' knowledge, understanding and memory of what was read in the text.

In phase two, it is cooperative learning group roles or students collaboration. After the students are proficient in using CSR steps with the help of the teacher, they are ready to implement the steps in their own group. Johnson and Johnson (1989 in Klingner, 2007: 146) explain that "cooperative learning should promote and include five main characteristics: (a) positive interdependence, (b) considerable face to face interaction among students, (c) individual accountability, (d) positive social skills, and (e) self as well as group evaluation or reflection". In cooperative groups students will discuss what they have read, and they support one another to comprehend the text. Here, everyone has a chance to try out all of the roles. Those are leader, clunk expert, gist expert and announcer. Leader will guide the discussion in a group, while the clunk expert lead the group to find out the difficult word or idea and gist expert will make the group in the track of discussion. Moreover, announcer makes sure that all of the members speak up.

Collaborative Strategic Reading (CSR) is an approach that combines reading comprehension strategy instruction and cooperative learning. CSR improves students' reading comprehension, increases their vocabularies by doing click and clunk, enhances 
cooperative skills, and builds the adaptation with the other students. On the other hand, the weaknesses are the students require more time to understand the material because the teacher only presents the material and the students have to do some stages in Collaborative Strategic Reading by themselves. This study will make the students bored if the teacher cannot manage the classroom well. By seeing the strengths and weaknesses of the strategy, teachers have to consider these when applying the strategy in the classroom.

\section{METHOD}

This present study applied one kind of experimental research design which was quasi-experimental design. Quasi-experimental design involved selecting groups, upon which a variable was tested, without any random pre-selecting processed because the quasi-experimental research design does not provide full control. However, according to Ary, et al (2010:316), believes that quasi-experimental research design is beneficial because the researcher can reach the reasonable conclusion even though full control was not possible.

This study is carried out in SMPN 1 Gondanglegi Malang. The researcher used purposive sampling technique where the subjects were selected because of the characteristics that the researcher need. There were 63 students who participated in this study. Moreover, the experimental group was the students that were taught by using Collaborative Strategic Reading and the control group was the students that were given by Group Discussion.

Students in experimental group are divided into some groups in which every group consisted of one student who had good achievement in English proficiency. On other hand, the rest of students were divided by counting one until three. The material was about narrative text. Meanwhile, the control group was treated by using Group Discussion with the same material. Students were divided into some groups and they discussed without any steps to answer the question.

In this study, the data was collected by using some instruments which were test (include pre-test and post-test), and questionnaire. Test was the main instrument that was used to collect the data in this study. There were two kinds of test that were given to both groups. They were pre-test and post-test. The pre-test was used to identify students' level of language proficiency. Both experimental and control group were given a pre-test before getting treatment. The students will answer 10 multiple choices to check their understanding of the text and 5 essay questions in order to know how they comprehend the story by using short answer. Post-test was given to compare students' reading comprehension that was achieved by both experimental and control group after the treatment was given. The test consists of 10 multiple choices and 5 essay questions about the material that had been given during the treatment.

Further, the second instrument was questionnaire which consisted of some questions in order to gain information and respond about the subject of the study or even the study itself from the participants. The purpose of this instrument was to support the final result of the study by analyzing the answer from the participants. In this study the researcher used the multiple choice question that consist of questions about the preference in learning English especially in teaching reading by using Collaborative Strategic Reading. 
In order to know how far the instruments measured the data and how consistent the test that measured, the validity and reliability were needed. The purpose of the validity was to check the instruments of the research. Here the researcher used content validity. Content validity used to determine whether the contents of the test were appropriate and relevant to the objective of the study that used to measure. Before developing the test, the researcher developed the blueprint of it to show the content covered all the material that was given to the students. Next, the researcher tried out the test to students other than students who do not belong to control and experimental group and the experiment and control group and it did before pretest of both groups.

In this study, the researcher computed the $t$ value by using independent sample $t$ test in SPSS 22.0 program in order to answer the problem of this study by comparing the result of post-test from both groups. The estimation is if $t$ value is greater than 0.05 then hypothesis is accepted. It means Collaborative Strategic Reading is effective for teaching reading and for students' reading comprehension. If t-value is less than 0.05 then hypothesis is rejected and the effectiveness of Collaborative Strategic Reading is not found.

\section{FINDING}

The reliability of the test items was found based on the result of the try out. The Cronbach's alpha that was found in this study was 0.806 . So, based on the statement before the Cronbach's alpha of this study show the high consistency because it's already close to 1.00. Moreover, the result was in the range of $0.70-0.90$ in which shows the test items have a high reliability.

The result of pre-test from both groups showed that the mean of the pre-test of experimental group was 68.35 with a standard deviation 10.439. The mean score of the control group 66.41 with a standard deviation 13.521. Although the experimental group was higher than the control one 68.35>66.41, yet, the difference was not significant. It showed that the ability of the students was equal before the treatment was given. In the other word, the ability of the students was homogeneous in English subject.

Theoretically, if the probability (p) is less than 0.05 , so the null hypothesis $\left(\mathrm{H}_{0}\right)$ is rejected. But if the probability $(\mathrm{p})$ is more than 0.05 the null hypothesis $\left(\mathrm{H}_{0}\right)$ is accepted while alternative hypothesis $\left(\mathrm{H}_{\mathrm{a}}\right)$ is rejected. Based on the table 3.4 , the probability (p) was less than 0.05 , it was .000 . The researcher concluded that Collaborative Strategic Reading is an effective way to be applied.

In addition, the result showed that experimental group got greater mean score than the control group. The mean score gained by the experimental group was 74.58 while the mean score gained by the control group was 62.66. The statistical computation of differences in mean score by using independent sample t-test in SPSS 22.0 version was done to know the $t$ value gained by both groups.

The result showed that although in the pre-test the mean score of both group is not significant difference, the experimental group gained 68.35 and the control group gained 66.41, but in the post-test after giving the treatment by using Collaborative Strategic Reading, the experimental group got greater mean score than control group. The mean score gained by the experimental group was 74.58 while the mean score gained by the control group was 62.66 .

To know the students' response towards the application of Collaborative Strategic Reading in reading comprehension, the researcher gave a questionnaire to the participants. Only the experimental group was given the questionnaire because the 
Collaborative Strategic Reading was only applied in this group. The result of questionnaire was used to support the main data.

From the result that had been gotten from the questionnaire it could be concluded that students were interested with the application of Collaborative Strategic Reading in reading comprehension. Meanwhile, the result of post-test showed in figure 3.1 that experimental group got greater mean score than the control group. It means that applying Collaborative Strategic Reading is an effective way to teach narrative text. Moreover the students were motivated to study reading by applying this strategy.

\section{DISCUSSION}

The researcher decided to extend the research by identifying the effectiveness of Collaborative Strategic Reading on students' reading comprehension. As this research was quasi-experimental research, so the main data was gained through test given to the students after they got treatment. The result score that had been gotten by two groups showed a significant difference. As presented in the previous chapter, it showed that there were significant differences from both groups in the scores, because the probability (p) was smaller than the significant level $(.000<0.05)$. Therefore, it can be said that Collaborative Strategic Reading gave a positive effect on students' reading comprehension. Meanwhile, the control group which was given treatment by using Group Discussion did not get any improvement on their reading comprehension. Even they got lower mean score after being treated.

This result seems in line with the result of the previous study conducted by Putri, et al (2015). The result showed that Collaborative Strategic Reading could develop reading comprehension. It showed after doing the post-test, it was found that the highest score was 94.2 and the lowest score was 62.8. The researcher then calculated the mean score on post-test was 78.2. The students' percentage that did well or passed the test was $96 \%$ and $4 \%$ of students was categorized unsuccessful. These showed that students' achievement increased after the treatment.

In addition, there was a study by Lubis (2015). The result showed that there is a significant effect of applying Collaborative Strategic Reading on the students' achievement in reading comprehension. It found the mean of the post test for the experimental group was 76.76 and for the control group was 63.53. By using CSR the researcher said that the students are able to solve their problem in comprehending the text and bringing good improvement in students' reading achievement.

On the other hand, the control group which was treated by using Group Discussion as how the teacher usually uses got low improvement on their reading achievement. Although the mean score of pre-test from both groups were not significant difference, the post test showed that experimental group who was treated using Collaborative Strategic Reading had a good improvement in their achievement than the control group. There were two possibilities why the control group got low achievement after doing the post-test. First was because the students worked in a group that there were no steps to do the tasks. Everything just based on the teacher instructions. That is why some students understood while others did not.

Contradictory with the experimental group who was treated by using Collaborative Strategic Reading, students did the activities in the group with the clear steps. The second was because there was no role for each student to do their job, that is 
why some students felt confused and they did not know what they had to do in their group. While in the experimental group, they got role for each students and each role got steps to do their jobs clearly, so there were no students that did nothing in group.

This case supports the study conducted by Rana (2014). The result showed that by using Collaborative Strategic Reading, it shows a positive impact on the experimental group. The performance of the students in the experimental group who were exposed to the Collaborative Strategic Reading was found to be improved. Not only their achievement increased but also their confidence level increased and they felt satisfaction and capable of applying the strategy for reading any kind of textual material. That is because the role that each students had to speak up their job in a group.

As the researcher explained before, every student in experimental group had their own role to do their job in group such as leader, clunk expert, gist expert and announcer. They had their own card to make the discussion run well. From this, every student had to speak up what they had in their mind about the material discussed and that was a duty of the announcer. So there was no silent students in every group, they had to talk one by one and finished the task together. In this case, the situation motivated the students to learn how to comprehend a story and built their confidence to speak in front of their classmate even though just in a small group. This supports the previous study from Suwantharathip (2013). It was found that students improved their reading strategy after the intervention. It showed the students had gained more confidence because they had studied and worked together with their classmates.

Contradictory with study from Sari and Tama (2015), this study had found that there was no significant difference between the students who are taught using Collaborative Strategic Reading and the students who are taught using teacher centered teaching strategy in their reading achievement with regard to knowledge and comprehension levels. It also found that Collaborative Strategic Reading gave a small effect to the students in the Experimental Group. It showed $15.85 \%$ of improvement in the experimental group from their pretest scores to their posttest scores and it also showed that the improvement of the control group was lesser, which was only $9.71 \%$.

In that research, although the amount of the improvement of the experimental group was bigger than that of the control groups, concerning the effect, the Cohen "s $\mathrm{d}$ formula showed that the effect of the experimental group was only $d=0.24$, which means that the effect is small. Some possible explanation for this finding might the fact that the students did not have good ability in reading as in listening, speaking, and writing. Moreover, the students were getting bored after several meeting continuously with the reading class. As the result they answered the comprehension questions just as their obligation in order to fulfill teacher's instructions.

While the result of supporting data which was questionnaire showed good response from the students. $87 \%$ of participants or 31 students felt that the implementation of Collaborative Strategic Reading helped them to understand the story, while 28 students or $90 \%$ of the participants felt that steps in Collaborative Strategic Reading were easy to be followed, because all of them liked working in a group and 94\% of the them stated that the researcher explained the steps how to apply Collaborative Strategic Reading clearly.

While the result of students' attitude during teaching and learning process was also good enough. In the phase one, the students did not really pay attention on the researcher's explanation, and still did not understand the implementation of 
Collaborative Strategic Reading. It was because the classroom teacher never used Collaborative Strategic Reading as the method of teaching and learning before.

In order to avoid confusion in understanding teacher' instruction, the researcher divided the students into groups in which every group consisted of one student who had good achievement in English. It was based on their English performance and also the suggestion from the teacher. Meanwhile the group members were decided by counting one until three. On the other hand, in Phase Two, they started to show their curiosity by paying more attention to the researcher's explanation on what they did in the group with their own card's role (cue card). It was reflected on their answer in questionnaire, $87 \%$ of participants liked reading using Collaborative Strategic Reading.

\section{CONCLUSION}

According to the researcher during teaching English reading comprehension activities, the teaching and learning was passive. The teacher used traditional method. Moreover, the students still had some problems in reading comprehension, such as lack of vocabulary, had no interesting with the material, and also feel bored with the strategy. Thus, the researcher tried to help the students to find the solution of their problems by applying Collaborative Strategic Reading on students' reading comprehension. Collaborative Strategic Reading helped the students to increase their vocabularies by doing click and clunk, build the confidence of the students by the adaptation with the other students, helped the students to be responsible to themselves to understand the material well and prepared themselves to answer the questions given by the teacher.

Based on the finding from the previous chapter, the implementation of Collaborative Strategic Reading gave a positive effect on students' reading achievement. The result showed that experimental group got greater mean score than the control group. The mean score gained by the experimental group was 74.58 while the mean score gained by the control group was 62.66. So, descriptively, the experimental group got higher mean score than the control group $(74.58>62.66)$. It showed that there were significant differences from both groups in the scores, because the probability (p) was smaller than the significant level $(.000<0.05)$.

\section{REFERENCES}

Abidin, M. J.Z., \& Riswanto. 2012. Collaborative Strategic Reading (CSR) within cognitive and metacognitive strategies perspective. European Journal of Business and Management, 4, 61-69.

Ary, Donald. Jacobs, Lucy C. \& Sorensen, Chris. 2010. Introduction to Research in Education EIGHTH EDITION. Wadsworth, Cengage Learning. USA.

Diana Sari, Carolin. \& Tamah Siti. 2015. The effect of collaborative strategic reading on grade six students' reading achievement. IJEE (Indonesian Journal of English Education), 2 (1), P-ISSN: 2356-1777, E-ISSN: 24430390.

Fairy Tales. 2009 The aged Mother. Adopted from (http://www.fairytales.biz/brothersgrimm/the-aged-mother.html) diakses

19 Januari 2017 
Klingner, Janette K., Vaughn, and Broadman. 2007. Teaching Reading Comprehension to Students with Learning Difficulties. New York: The Guildford Press

Klingner, Janette. K. Vaughn, S., \& Schumm, J S. 2001. Collaborative strategic reading during social studies in heterogeneous fourth grade classrooms. Elementary School Journal. 2(5), 123-45.

Klingner, J. K., \& Vaughn, S. 1998. Collaborative strategic reading. Teaching exceptional children, 33 .

Klingner, Janette K. and Sharon Vaughn. 1998. Using Collaborative Strategic Reading. Teaching Exceptional Children Journal. Vol. 1, pp. 32-37.

Nikmah, Fiki Maulidatun. 2015. The Effect of Using Numbered Heads Togetger to the Seventh Grade Student's Reading Comprehension of Smp Negeri 8 Kediri In Academic Year 2014/2015. Skripsi. Kediri: FKIP UNP KEDIRI.

Putri, Aisyah Kahar. Ohoiwutun, Jos E \& Wahyudin. 2015. Using collaborative strategic reading (CSR) to develop reading comprehension of the second year

student. E-journal of English language teaching society(ELTS), vol $3 \quad$ no 22015 ISSN 2331-1841

Puspita, Rayindra Mayang. Tasnim, Zakiyah \& Ariyanto, Sugeng. 2013. The Effect Of Collaborative Strategic Reading (Csr) On The Eleventh Grade

Students' Reading Comprehension Achievement At Sma Negeri 2 Bondowoso.

Pancaran, Vol. 2, No. 2, hal 1-12, Mei 2013.

The IRIS Center. 2008. CSR: A reading comprehension strategy. Retrieved from (http://iris.peabody.vanderbilt.edu/module/csr/) diakses 5 Januari 2017

White, Howard. \& Sabarwa, Shagun. 2014. Quasi-Experimental Design and Methods. 50122 Florence, Italy.

English Language Teaching Resources. 2011. Engligh Worksheet for Teacher and Learner. Adopted from (englishwsheets.com) diakses 7 Januari 2017 